\title{
A Presentation without an Example?
}

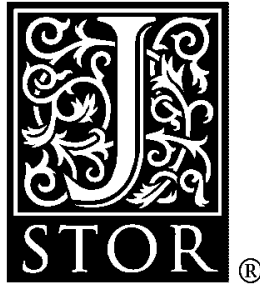

\author{
Arnold Zuboff
}

Analysis, Vol. 52, No. 3. (Jul., 1992), pp. 190-191.

Stable URL:

http://links.jstor.org/sici?sici=0003-2638\%28199207\%2952\%3A3\%3C190\%3AAPWAE\%3E2.0.CO\%3B2-P

Analysis is currently published by The Analysis Committee.

Your use of the JSTOR archive indicates your acceptance of JSTOR's Terms and Conditions of Use, available at

http://www.jstor.org/about/terms.html. JSTOR's Terms and Conditions of Use provides, in part, that unless you have obtained prior permission, you may not download an entire issue of a journal or multiple copies of articles, and you may use content in the JSTOR archive only for your personal, non-commercial use.

Please contact the publisher regarding any further use of this work. Publisher contact information may be obtained at http://www.jstor.org/journals/anacom.html.

Each copy of any part of a JSTOR transmission must contain the same copyright notice that appears on the screen or printed page of such transmission.

The JSTOR Archive is a trusted digital repository providing for long-term preservation and access to leading academic journals and scholarly literature from around the world. The Archive is supported by libraries, scholarly societies, publishers, and foundations. It is an initiative of JSTOR, a not-for-profit organization with a mission to help the scholarly community take advantage of advances in technology. For more information regarding JSTOR, please contact support@jstor.org. 
calculators have the relevant arithmetical beliefs. The difficulty with this line is that the case of simple attentive miscalculation may be one in which the simple attentive miscalculator explicitly says: 'next, 2 and 3 is 6'. The words may not be produced mechanically or automatically, in the way in which one might unthinkingly repeat a poem that he has memorized. Something about the miscalculator's belief state seems to be relevant to the explanation of the miscalculation. This would seem to make a simple miscalculation quite unlike a subact of a skilled knowinghow to do something which has misfired, or of a habit which has not been fully inculcated or developed.

I know that simple attentive miscalculation occurs, but I do not know how it is possible that it occurs. The explanation of an unintentional simple attentive miscalculation must include some belief, but there is no plausible candidate belief which one can attribute to the miscalculator that will explain that miscalculation. ${ }^{1}$

The London School of Economics, Houghton Street, London WC2A $2 A E$.

'I wish to thank Simon Ruben (above all), R. M. Sainsbury, Paul Noordhof, many who attended a seminar at the London School of Economics at which this paper was read, Peter Smith, and an anonymous referee for Analysis for their help in writing this paper.

\title{
A PRESENTATION WITHOUT AN EXAMPLE?
}

\section{By ARnold ZuborF}

\begin{abstract}
TN A DREAM someone said to me, 'Any general thesis which is I put forward without a concrete example is therein badly presented'. That was all he said, and I was about to point out the irony that in merely putting forward this thesis by means of a general statement the speaker had failed his own requirement of providing an example when it suddenly occurred to me, as I exclaimed to him, 'Ah, I see. Your putting forward this thesis without an example is itself the concrete example'. But when I awoke I realized there was a problem here. If indeed the speaker is credited with having given me a concrete example of an exampleless bad presentation, then that credit must be immediately withdrawn, because what he has given me is not an example of an example-less bad presentation. But if it is not an example, then it must once again be received as an example of example-less presentation, but then it once again is not an example, and so on forever.
\end{abstract}


This is another paradox of inclusion, like Russell's paradox. What I think may make this one especially interesting is that it could turn out to be resistant to certain popular treatments of such paradoxes. This paradox arises involving natural predicates in a natural expression of a natural - if somewhat exaggerated thesis.'

University College London, Gower Street, London WC1E 6BT

'I am happy to thank Jerry Valberg, Jo Wolff, Malcolm Budd and G. A. Cohen for their advice and encouragement.

\title{
I FALSELY BELIEVE THAT $P$
}

By Mark Crimmins

'You have known me for years', explained Gonzales, 'But there is something you have not discovered. You know me under two guises, just as Lois Lane knows Superman. You do not realize that I am the person you know under another guise. On that way of thinking about me, you have quite different opinions of me. In fact, you think me an idiot.'

'Knowing your cleverness', I replied, 'I must with some embarrassment accept what you say. Since I do not know what guise you mean, I do not know which belief to revise. Until I find out, it seems, I falsely believe that you are an idiot!'

Comell University,

Ithaca, NY 14853, USA

\section{A NOTE ON LEWIS'S ONTOLOGY}

ByJoseph Melia

\begin{abstract}
A CCORDING TO LEWIS, possible worlds are the same kind of A object as the actual world. For Lewis, possible worlds are concrete, spatio-temporally extended entities, containing causally efficacious objects (see Lewis [1], pp. 84-91 and Lewis [2] for details).

One obvious criticism of this theory of possible worlds is that it is ontologically unparsimonious: the plurality of distinct possible worlds Lewis needs to represent every possible way the world could have been is a large plurality indeed.
\end{abstract}

